\title{
Direction Control of Information Transfer between Neuronal Populations with Asymmetric Three-Dimensional Microstructure
}

\author{
Shohei Hattori Non-member (The University of Tokyo, hattori@hnl.t.u-tokyo.ac.jp) \\ Jun Suzurikawa Student Member (The University of Tokyo, suzuri@brain.imi.i.u-tokyo.ac.jp) \\ Ryohei Kanzaki Non-member (The University of Tokyo, kanzaki@i.u-tokyo.ac.jp) \\ Yasuhiko Jimbo Member (The University of Tokyo, jimbo@k.u-tokyo.ac.jp) \\ Tetsuya Hamaguchi Non-member (The University of Tokyo, hama@hnl.t.u-tokyo.ac.jp) \\ Hirokazu Takahashi Member (The University of Tokyo, takahashi@i.u-tokyo.ac.jp) \\ Masayuki Nakao Member (The University of Tokyo, nakao@hnl.t.u-tokyo.ac.jp)
}

Keywords : neuronal population, information transfer, cell culture, 3D microstructure, calcium imaging

Information transfer among neuronal populations has directional bias. Some past studies demonstrated that microstructure can bias a direction of information transfer at a cellular level. However the transfer at a population level has been hardly controlled. Here, in order to control the information transfer we attempt to bias direction of neurite outgrowth of cultured neurons with a three-dimensional asymmetric microstructure.

The proposed microstructure is an embossed barrier with a rectangular-triangle cross section, namely an ascending slope and vertical wall. Because of its asymmetricity, a neurite growth rate from the wall-side to slope-side is expected to be suppressed as compared with that of slope-to-wall. The fabricated substrate is shown in Fig. 1. The microstructure was fabricated on polystyrene substrate by hot press with a metal die. At the same time as hot pressing, we also embedded tungsten microelectrodes in both sides of the structure for probing stimulation. The master structure on the metal die was fabricated by linear cutting with a monocrystal diamond tool. The wall height and slope angle were $20 \mu \mathrm{m}$ and 12 degree, respectively.

To investigate impact of the microstructure on neurite outgrowth, and thus information transfer direction between

(b)

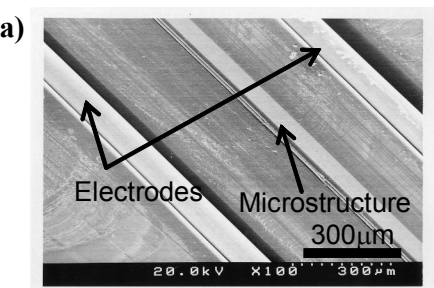

(i)

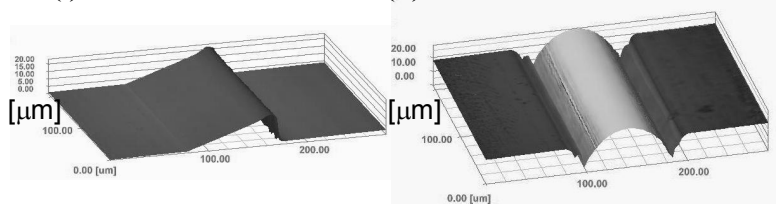

(a) A scanning electron micrograph. (b) 3D profiles of microstructure (i) and electrode (ii) measured by the confocal laser scanning microscope.

Fig. 1. A fabricated microstructure and embedded electrodes neuronal populations separated by the structure, we stimulated cultured neurons on both the sides of the structure. The fluo- 4 calcium imaging was used to observe spiking responses of neurons. Figure 2(a) shows fluorescence transients of the two areas evoked by wall- and slope-side stimuli. The neuronal population on the wall side responded nearly equally to both the stimuli from wall-side $\left(\mathrm{R}_{\mathrm{ww}}\right)$ and slop-side electrodes $\left(\mathrm{R}_{\mathrm{ws}}\right)$, whereas that on the slope-side responded more strongly to the slope-side stimulation $\left(\mathrm{R}_{\mathrm{ss}}\right)$ than to wall-side $\left(\mathrm{R}_{\mathrm{sw}}\right)$. Consequently, as shown in Fig. 2(b), the normalized peak response value of $R_{s w}$ were significantly smaller than that of $R_{w s}$ (t-test, $\mathrm{p}=0.012 ; \mathrm{n}=5)$. This result strongly suggests that information transfer between neuronal populations separated by the asymmetric structure had directional bias.

(a)
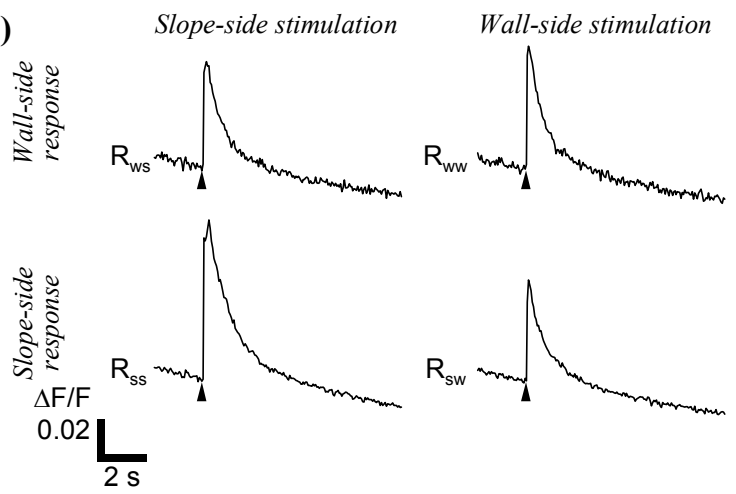

(b)

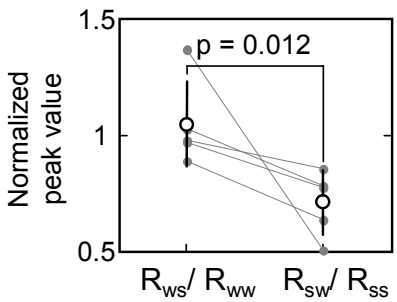

(a) Fluorescence transients evoked by slope- and wall-side stimuli. Transients were spatially averaged among responsive pixels in each area. Arrow heads indicate stimulus timing. (b) Comparison of peak response values in contra-stimulus areas.

Fig. 2. Electrical-stimulus-evoked responses in two areas separated by the asymmetric micro structure 


\section{非対称な三次元微細構造を用いた神経細胞群間の 情報伝達方向制御}

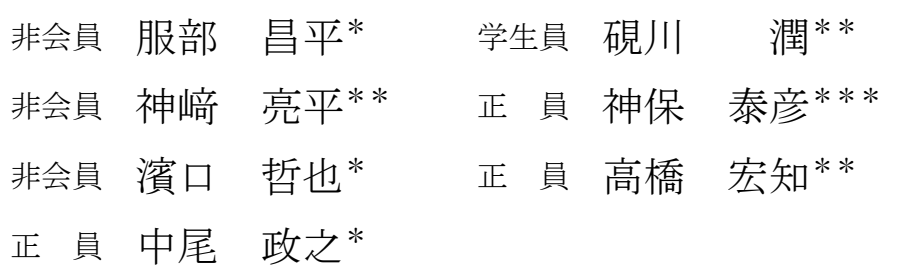

\section{Direction Control of Information Transfer between Neuronal Populations with Asymmetric Three-Dimensional Microstructure}

Shohei Hattori*, Non-member, Jun Suzurikawa**, Student Member, Ryohei Kanzaki**, Non-member, Yasuhiko Jimbo***, Member, Tetsuya Hamaguchi*, Non-member, Hirokazu Takahashi**, Member, Masayuki Nakao*, Member

Information transfer among neuronal populations has directional bias. Some past studies demonstrated that microstructure can bias a direction of information transfer at a cellular level. However the transfer at a population level has been hardly controlled to date. Here, in order to control the information transfer we attempt to bias direction of neurite outgrowth of cultured neurons with a three-dimensional asymmetric microstructure. The proposed microstructure is an embossed barrier with a rectangular-triangle cross section, namely an ascending slope and vertical wall. Because of the asymmetricity, a neurite growth rate from the wall-side to slope-side is expected to be suppressed as compared with that of slope-to-wall. We fabricated the microstructure on a polystyrene substrate by hot press, simultaneously embedding line-electrodes for probing stimulation. To confirm impact of the microstructure on neurite outgrowth, and thus signal transfer direction between neuronal populations separated by the structure, we stimulated cultured neurons on the both sides of the structure. There was difference in neuronal responses to wall-side stimulation and slope-side one, demonstrating the directional characteristic of information transfer.

キーワード : 神経細胞群, 情報伝達, 細胞培養, 三次元微細構造, カルシウムイメージング

Keywords : neuronal population, information transfer, cell culture, 3D microstructure, calcium imaging

\section{1. はじめに}

大脳皮質では，例えば 4 層から $2 / 3$ 層へというように，神 経細胞群間の情報伝達方向に指向性が見られる(1)(2)。このよ うな細胞群間の情報伝達モデルを培養神経系に構築できれ

ば，大脳皮質の情報処理基盤を解明するための強力な手法

* 東京大学大学院工学系研究科

干113-8656 東京都文京区本郷 7-3-1

Graduate School of Engineering, The University of Tokyo

7-3-1 Hongo, Bunkyo-ku, Tokyo 113-8656

** 東京大学大学院情報理工学系研究科

于113-8656 東京都文京区本郷 7-3-1

Graduate School of Information Science and Technology, The University of Tokyo

7-3-1 Hongo, Bunkyo-ku, Tokyo 113-8656

*** 東京大学大学院新領域創成科学研究科

T277-8561 千葉県柏市柏の葉 5-1-5

Graduate School of Frontier Sciences, The University of Tokyo

5-1-5 Kashiwanoha, Kasiwa-shi, Chiba 277-8561
になると考える。これまでに, フォトリソグラフィ等の微 細加工技術で製作された構造を用いて，ごく少数の細胞間 の情報伝達経路の制御が試みられてきた (3) (7)。しかし, 多 数の神経細胞で構成された細胞群間の情報伝達を制御する 手法は未だ確立されていない。これは, 従来の研究が, 個々 の神経細胞の位置や軸索伸長経路を制御することに重点を 置いてきたためであると考えられる。フォトレジスト(3)やア ガロース ${ }^{(6)}$ で神経回路の鋳型を製作し, そこに単一細胞をは め込んでいくという従来の手法では, 拡張できる神経回路 の規模に限界がある。一方, 個々の細胞への操作を用いず に神経回路の成長過程を制御する試みとして, サブ $\mu \mathrm{m}$ から 数 $\mu \mathrm{m}$ オーダの微細パターンで表面全体を修飾した培養基 板が開発されている(8)(9)。しかし, これらの研究は, 神経細 胞の形態的な特徵のみに着目したものが大半であり, 情報 伝達方向やその指向性といった神経回路の機能に与える影 
響は検証されていない。

そこで本研究では, 緩斜面と垂直壁面とから成る非対称 な三次元微細構造を用いて, 同構造で隔てられた培養神経 細胞群間の情報伝達方向を制御することを試みた。壁面側 から緩斜面側と，その逆方向への神経突起の伸長に差がで きることで，各方向への神経信号伝達を担うシナプス結合 の数に差ができ, 両群間の情報伝達に指向性が生じると考 える。この仮説を検証するために, 微細構造の両側に刺激 電極を設け，それぞれの電気刺激で誘発される神経回路の 反応をカルシウムイメージングで計測した。

\section{2. 神経培養基板の製作}

$\langle 2 \cdot 1\rangle$ 基板の設計 本研究で提案する培養基板の概 念図を図 1(a)に示す。切削加工で微細溝を成形した金属板を

(a)

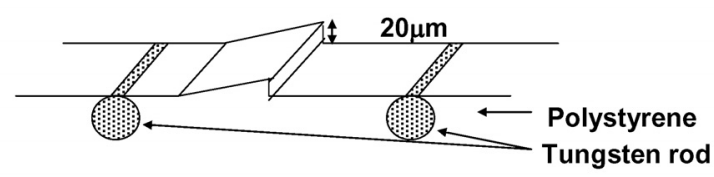

(b)

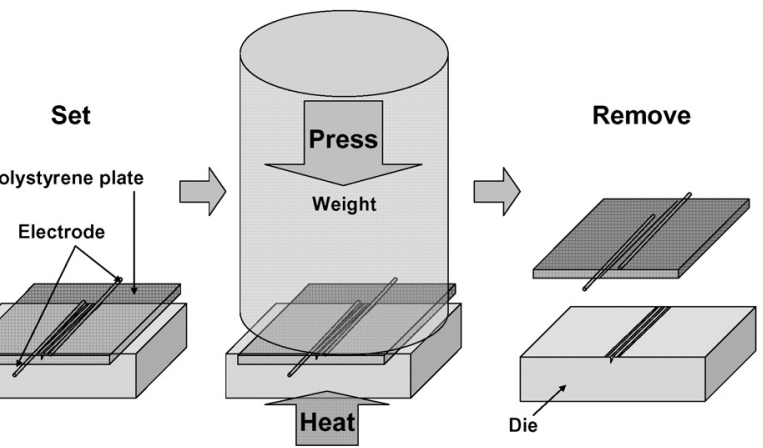

(c)

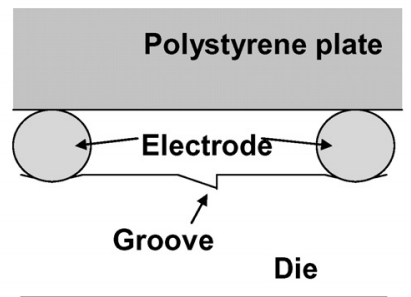

(a) Schematic diagram of the microstructure. (b) A process flow of hot press. (c) A detailed cross section sketch in hot pressing.

Fig. 1. A proposed 3D microstructure.

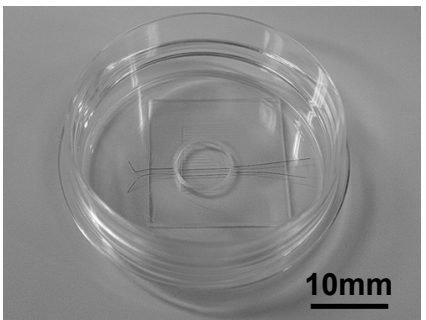

Fig. 2. Whole view of the chamber-attached substrate.
金型として，樹脂基板に三次元構造を転写した。金型に設 置したタングステンロッドを基板中に包埋することで，転 写と同時に刺激電極を形成できる。

形状の転写には，熱可塑性樹脂を金型に押し付けて加熱 するホットプレスを用いた。基板材料には，(1)形状が精度 良く転写されるために必要な流動性を持つこと, (2)材料が 電極下に回りこまないように十分な粘度を持つこと, (3)生 体適合性が良いこと, が求められる。以上の条件を踏まえ, 培養シャーレとして広く用いられており, 熱可塑性を有す るポリスチレンを基板材料として用いた。(1)と(2)はトレー ドオフの関係にあるが, 後述するようにプレス時の温度を 適切に設定することで, 両者を満たすことができる。

〈2·2〉 製作工程 工程の概要を図 1(b)に示す。市販 のポリスチレン製培養シャーレ (Corning, Cell Culture Dish 430166) を切断し, 厚さ $0.8 \mathrm{~mm}, 20 \mathrm{~mm} \times 20 \mathrm{~mm}$ の基板を切 り出した。このポリスチレン基板と直径 $100 \mu \mathrm{m}$ のタングス テンロッドをそれぞれ図1(c)に示したように金型に設置し， $100 \mathrm{MPa}$ の圧力を与えながらホットプレート (Iuchi,

(a)

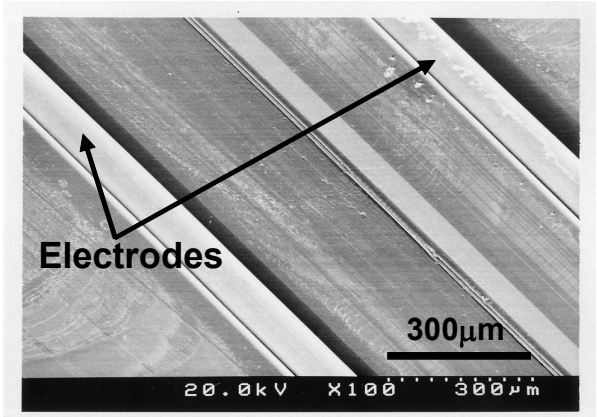

(b)

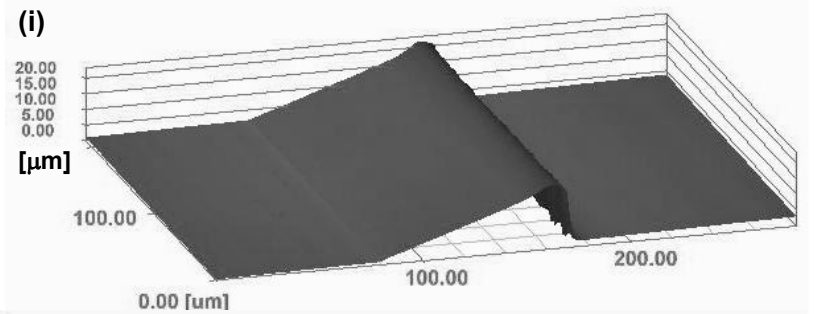

(ii)

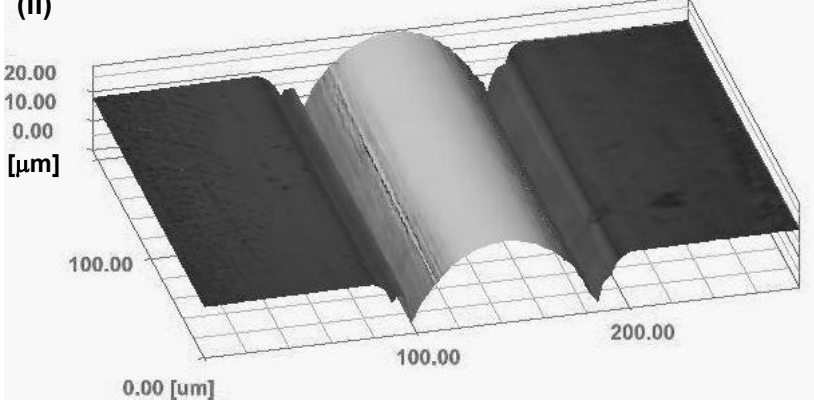

(a) A scanning electron micrograph of the microstructure and embedded electrodes. (b) 3D profiles of the microstructure (i) and electrode (ii) measured by the confocal laser scanning microscope.

Fig. 3. A fabricated microstructure and embedded electrodes. 

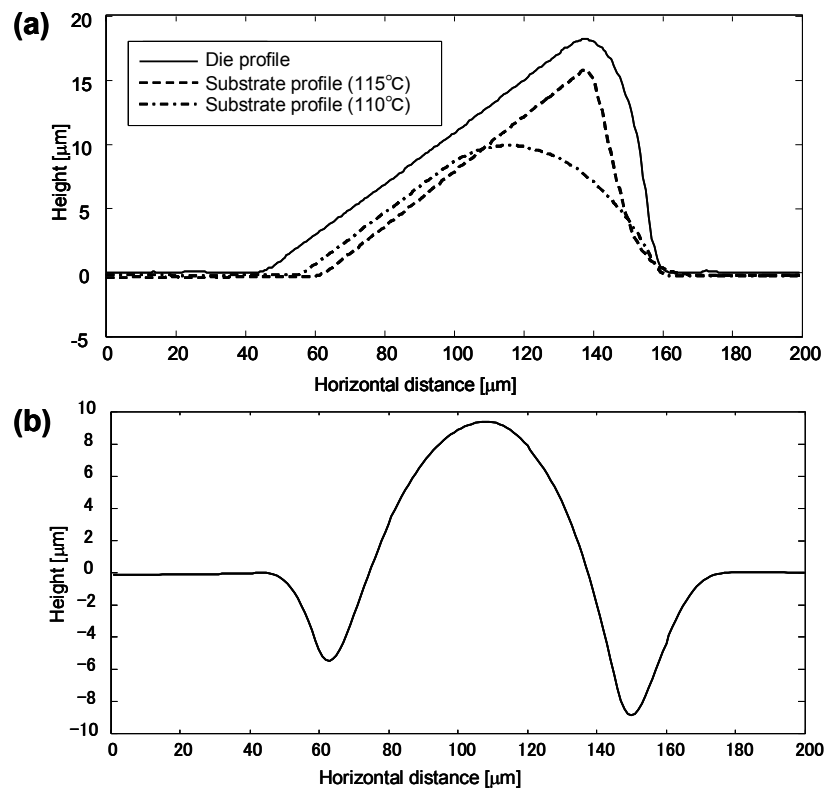

Fig. 4. Surface profiles of the die and fabricated 3D microstructure (a), and an embedded electrode (b).

EC-1200) 上で 3 時間加熱した。自然冷却後に基板を金型か ら取り外し，シリコーン接着剤でプラスチックシャーレを 接着した。製作した培養基板を図 2 に示す。なお，三次元 微細構造の壁面高さは $20 \mu \mathrm{m}$ ，緩斜面の傾斜角は 12 度，同 構造と電極との間隔は $500 \mu \mathrm{m}$ とした。Li らの研究では, 20 $\mu \mathrm{m}$ の壁面を乗り越える軸索の割合はおよそ $10 \%$ 程度と報 告されており ${ }^{(10)}$ ，壁面側から緩斜面側への軸索伸長を抑制 するために適切な值であると考える。

〈2·3〉 試作基板の評価適切な加工条件を決めるた めに，ホットプレートの加熱温度を $110,115,120{ }^{\circ} \mathrm{C}$ と変 化させて基板を試作した。その後，レーザ共焦点顕微鏡 (KEYENCE，VK-9510) および触針式表面形状測定装置 (Veeco, Dektak3) を用いて, 三次元構造の転写精度を評価 した。

加熱温度を $115{ }^{\circ} \mathrm{C}$ 設定した際に，三次元構造が精度良 く転写され，電極表面が露出した適切な基板が多く得られ た。同基板の走查型電子顕微鏡 (scanning electron microscope, SEM) 像を図 3(a)に, 三次元微細構造と包埋され た電極の表面形状をレーザ顕微鏡で計測した結果を図 3(b) に，それぞれ示す。三次元微細構造が凹凸無く均一に転写 され, 電極が基板表面に高さ約 $10 \mu \mathrm{m}$ の露出部分を残して 設計通りに埋め込まれていることが分かる。また，使用し た金型と基板の表面形状を触針式表面形状測定装置でそれ ぞれ計測した結果を図 4 に示す。図 $4(\mathrm{a})$ の $110{ }^{\circ} \mathrm{C}$ と $115{ }^{\circ} \mathrm{C}$ で製作した基板の表面形状から，温度が高い方が転写精度 は高くなることが分かる ${ }^{(11)}$ 。しかし，加熱温度を $120{ }^{\circ} \mathrm{Cま}$ で上げると，金型と電極との間に樹脂が流入し，電極表面

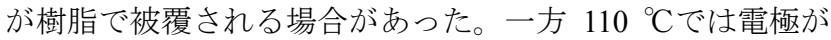
十分に基板に包埋されず，容易に脱落した。以上のように
温度を適切に設定することで良好な転写精度と電極の包埋 が得られることがわかった。

\section{3. 電気刺激実験}

〈3·1〉 実験方法 三次元微細構造の両側で, 神経細 胞群間の情報伝達方向に指向性が生じていることを確認す るために，基板上で培養した神経細胞に，壁面側・緩斜面 側それぞれの刺激電極を用いて電気刺激を与え，それによ り誘発される神経応答をカルシウムイメージングで計測し た。カルシウムイメージングは, 細胞内にカルシウム感受 性色素を導入することで, 細胞内のカルシウムイオン濃度 変化を蛍光強度変化として測定する手法である ${ }^{(12)}$ 。神経細 胞内のカルシウムイオン濃度は活動電位に伴って上昇する ため, 同イオン濃度変化は神経細胞の発火活動と相関する と考えられている(13)。

胚齢 18 日のラット胎児から摘出・解離した大脳皮質の神 経細胞を, poly-D-lysine・laminin をコーティングした基板上 に播種・培養した ${ }^{(14)(15)}$ 。細胞の播種密度は，およそ 12000 cells $/ \mathrm{mm}^{2}$ とした。グリア細胞の過剰な増殖を抑えるために, 播種後 24 時間は，5\%の B-27 supplement (Gibco, 17504), $0.5 \mathrm{mM}$ の L-glutamine， $25 \mu \mathrm{M}$ の L-glutamate をそれぞれ加 えた無血清培地 (Neurobasal; Gibco, 21103) で培養し, その 後, 血清入りの培地に置換した。血清入り培地には，5\%の 非動化したウマ血清とウシ胎児血清, 及び抗生物質とイン シュリンを添加した DMEM 培地 (Gibco, 11965) を用いた。 培地は, 週に 2 回の頻度で, 半量ずつ交換した。刺激実験 は播種後 15〜40 日で行った。イメージングのためのプロー ブ色素には fluo-4 (Molecular Probes) を用い，実験前に 10 $\mu \mathrm{M} \cdot 40$ 分間で細胞に負荷した。計測には 10 倍の水浸対物 レンズ (オリンパス, UMPlanF1 10×W; NA=0.30) を取り付 けた正立顕微鏡 (オリンパス, BX51W1) を用い, 冷却 CCD カメラ (浜松ホトニクス, C-9100-02) で $500 \times 500$ 画素の蛍 光像を取得した。なお, 各フレームの露光時間は $40 \mathrm{~ms}$, 取 得速度は $20 \mathrm{~Hz}$ で, 1 画素あたり 14 bit で記録した。電気刺 激には, パルス幅 $1 \mathrm{~ms}$ ・振幅 $1.5 \mathrm{~V}$ の複相性定電圧矩形波を 用い，陰極性・陽極性の順に印加することで電荷をバラン スさせた。刺激電圧は, タングステン電極とシャーレ中に 配置したステンレスワイヤとの間に印加した。ステンレス ワイヤは，シャーレの壁面に沿わせて円周状に配置し，シ ヤーレ上の神経細胞に接触しないように溶液中に浮かせて 固定した。実験中は, $149 \mathrm{mM} \mathrm{NaCl}, 2.8 \mathrm{mM} \mathrm{KCl}, 2 \mathrm{mM}$ $\mathrm{CaCl}_{2}, 1 \mathrm{mM} \mathrm{MgCl}_{2}, 10 \mathrm{mM}$ HEPES, $10 \mathrm{mM}$ glucose をそれ ぞれ含む溶液を, 細胞外溶液として用いた。

得られた蛍光像の解析では，壁面側・緩斜面側それぞれ の電極からの刺激で誘発された両領域での反応を算出し た。まず, 刺激直後の蛍光強度変化率を画素ごとに求め, 平均から 3 の以上の变化率を示した領域を反応性領域とし て抽出した。次に, 壁面側・緩斜面側それぞれの反応性領 域内で蛍光強度変化を空間的に平均化することで，蛍光強 度の経時変化を求めた。これ以降, 例えば壁面側刺激で誘 
発される緩斜面側の反応を $\mathrm{R}_{\mathrm{sw}}$ というように，壁面側を $\mathrm{w}$, 緩斜面側を $\mathrm{s}$ でそれぞれ表し，各反応の属性を反応領域・刺 激領域の順に示して記述する。

〈3.2〉実験結果図 5 に, 培養基板上の神経細胞の 位相差顕微鏡像を示す。神経細胞が正常に基板に接着し, 神経突起を伸長させていることがわかる。三次元構造の周 辺にも細胞は一様に分布しており，緩斜面側から壁面側及 びその逆方向にも神経突起が伸長する様子が観察された。 しかし，長期間にわたる培養を意図して高密度に細胞を播 種したため, 三次元構造が神経突起の伸長に与えた影響を 定量的に検証することは困難であった。

異なる 5 試料を用いた刺激実験の結果を図 6 に示す。図 6(a)に示したように，電極周辺を除いた領域から $\mathrm{R}_{\mathrm{ws}}, \mathrm{R}_{\mathrm{ww}}$ ， $\mathrm{R}_{\mathrm{ss}}, \mathrm{R}_{\mathrm{sW}}$ の経時変化をそれぞれ抽出した。図 6(b)に，培養 32 日目の試料を刺激して得られた蛍光強度の経時変化を示 す。いずれの反応においても, 刺激直後に急峻な蛍光強度 の立ち上がりが見られた。本研究では，蛍光強度を個々の

(a)

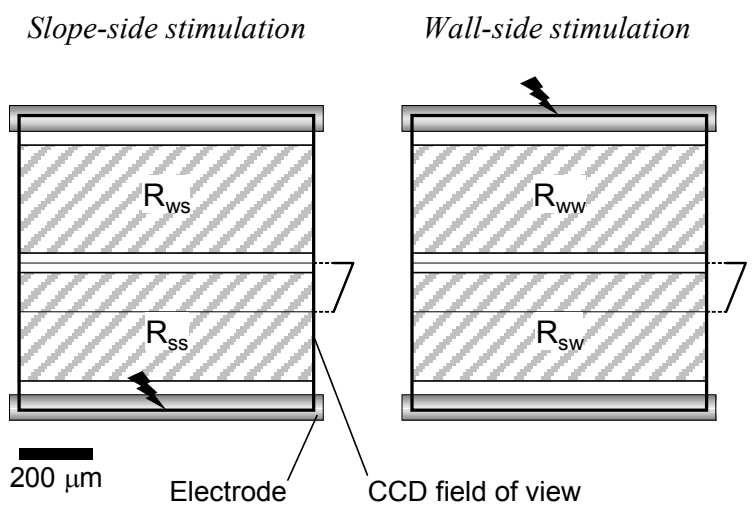

(c)

(i)

(ii)
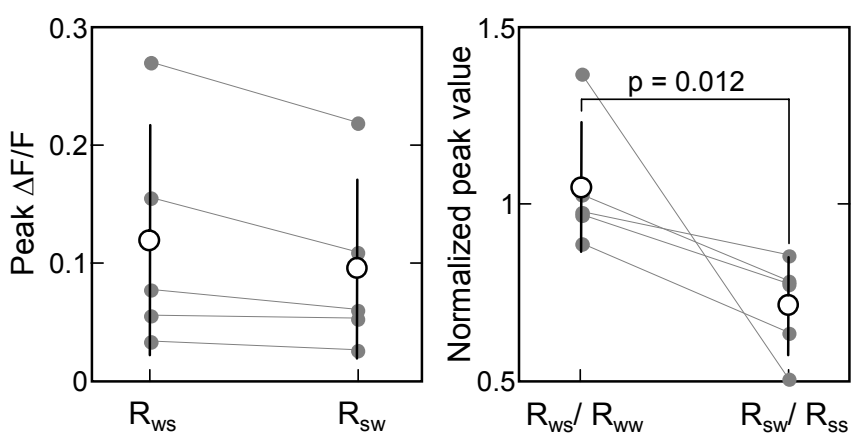

細胞ごとに算出していないため, 図 6(b)の経時変化にはグリ ア細胞の反応に起因した変化も含まれている。しかし，グ

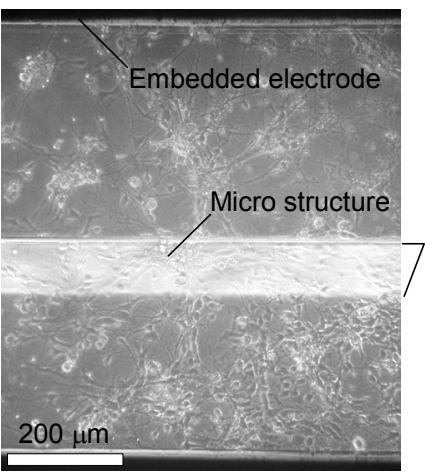

A cross section profile of the micro structure is shown at the right.

Fig. 5. A phase contrast image of a 4-day in vitro culture on the substrate. (b)

(i)
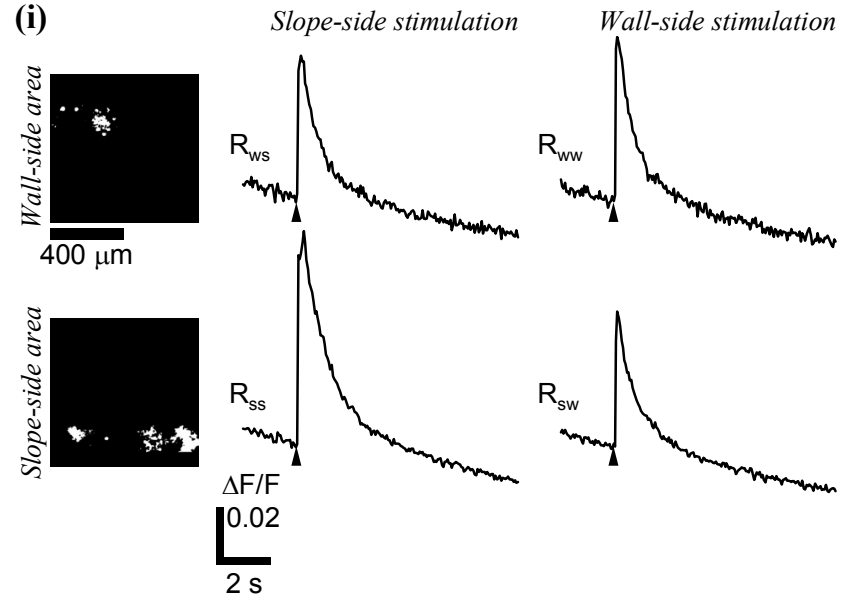

(ii)

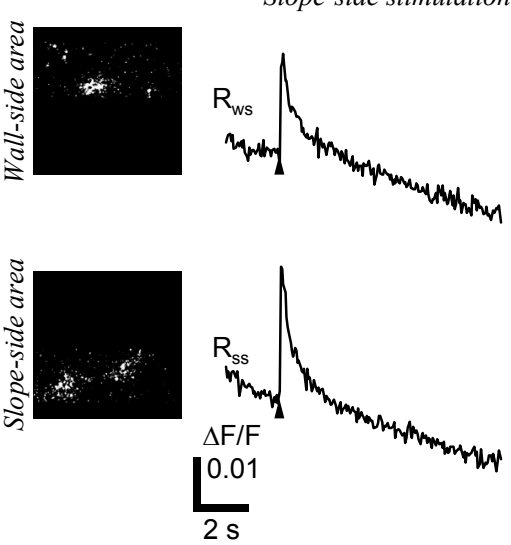

Wall-side stimulation
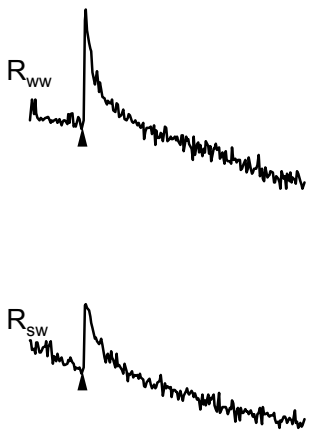

(a) Schematic diagram of response analysis. Four responses, namely, responses of two areas evoked by two different stimuli from slope-side and wall-side electrodes, were defined as $R_{w s}, R_{s s}, R_{w w}$ and $R_{s w}$. (b) Fluorescence transients evoked by slope- and wall-side stimuli. Results from two different experiments are shown. Transients were spatially averaged among responsive pixels in each area, which are shown in the left insets. Arrow heads under the transients indicate stimulus timing. (c) Comparison of peak response values in contra-stimulus areas. Raw peak values (i) and normalized peak values (ii) are shown respectively.

Fig. 6. Electrical-stimulus-evoked responses in two areas separated by the asymmetric micro structure. 
リア細胞では，電気刺激に対してこのように急峻な細胞内 カルシウムイオン濃度の増加は見られないことが報告され ている(16)。よって, ここで得られた蛍光強度変化は, 抽出 した領域の神経細胞群の活動を主として反映していると考 える。なお，電極の直上では，グリア細胞に特有の緩やか で持続的な蛍光強度の上昇が見られたため, 電極周辺部は 解析領域から除外した。個々の反応同士を比較すると, 壁 面側での反応 $\left(\mathrm{R}_{\mathrm{ws}}, \mathrm{R}_{\mathrm{ww}}\right)$ が刺激位置に依存した変化をほと んど示していないのに対して, 緩斜面側での反応 $\left(\mathrm{R}_{\mathrm{ss}}, \mathrm{R}_{\mathrm{sw}}\right)$ では，ピーク值に大きな差が見られた。この傾向は，図 6(b, i)に示したように両側の反応性領域の面積に大きな差があ る場合も, (b, ii)のようにほぼ面積が等しい場合も一貫して 観察された。

刺激側と反対の領域の反応，すなわち $\mathrm{R}_{\mathrm{sw}}$ と $\mathrm{R}_{\mathrm{ws}}$ は，電気 刺激で直接誘発される反応が支配的な $R_{s s}$ や $R_{w w}$ と比較し て, 両領域間の情報伝達特性を強く反映していると考えら れる。そこで, 図 6(c,i)に，5 試料分の刺激結果について， $\mathrm{R}_{\mathrm{sw}}$ と $\mathrm{R}_{\mathrm{ws}}$ のピーク值を比較して示した。細胞への色素負荷 量, 裉色の度合, 細胞密度などが試料によって異なるため 絶対值のばらつきは大きいが，どの試料でも一貫して $\mathrm{R}_{\mathrm{sw}}$ より $\mathrm{R}_{\mathrm{ws}}$ のピーク值が大きかった。ばらつきを相殺して $\mathrm{R}_{\mathrm{sw}}$ と $\mathrm{R}_{\mathrm{ws}}$ のピーク值を比較するために, 同側刺激で誘発された 反応との相対值を図 6(c,ii)に示した。相対值とその標準偏差 は， $\mathrm{R}_{\mathrm{ws}}$ では $1.04 \pm 0.19, \mathrm{R}_{\mathrm{sw}}$ では $0.71 \pm 0.14$ となり， $\mathrm{R}_{\mathrm{sw}}$ の 方が有意に小さいことがわかった $(\mathrm{t}$ 検定, $\mathrm{p}=0.012)$ 。

図 6 に示した結果は, 三次元微細構造で隔てられた神経 細胞群間の情報伝達に, 何らかの非対称性が存在すること を示している。 $\mathrm{R}_{\mathrm{ws}}$ と $\mathrm{R}_{\mathrm{sw}}$ のピーク值は, 両領域の神経細胞 群の, 反対領域からのシナプス入力に誘発された活動電位 の総数と相関していると考えられる。よって, $\mathrm{R}_{\mathrm{sw}}$ が $\mathrm{R}_{\mathrm{ws}}$ よ りも有意に小さいという結果から，両領域の神経細胞群間 の情報伝達には, 緩斜面側から壁面側への方向に指向性が 存在していると推測できる。

\section{4. 考察}

本研究では，三次元微細構造と刺激電極を有する培養基 板を，金型を用いたホットプレスで製作した。フォトリソ グラフィやドライエッチング等の半導体製造技術を用いた 製作手法と比較して, 本手法は，i）特殊な装置が不要で, 実験室レベルの簡易な設備を用いて製作できる点，ii）刺激 電極を同時に加工できる点, iii) 切削工具の形状を変えるこ とで, 緩斜面の角度等を容易に変更できる点で有利である と考える。特に, 緩斜面のように不等エッチングが必要な 場合, フォトリソグラフィとエッチングの組み合わせでは, 煩雑な条件出しを設計值の変更ごとに行う必要がある。ま た, $20 \mu \mathrm{m}$ の壁面高さをフォトリソグラフィで確保すること も困難であり，切削と転写を組み合わせた本手法が最も有 用であると考える。

金型の形状に対する成形形状の寸法誤差は，図 4(a) に示 したように, 約 10\%であった。これは, 加熱時と冷却後の
温度差による樹脂の収縮が原因である。しかし，相対的な 形状は正確に転写されており, 転写の再現性も高いため, 収縮を考慮して金型を設計することで， $\mu \mathrm{m}$ オーダの精度で 所望の寸法を容易に実現できると考える。また, 電極周辺 には, 図 4(b) に示したように, 樹脂の充填不良から $5 \mu \mathrm{m}$ 程度の溝が残る場合があった。しかし, この溝の深さは神 経細胞の平均的な直径よりも小さく, $\mathrm{Li}$ らの研究でも神経 突起の伸長を阻害しない高さとされているため ${ }^{(10)}$, 電極の 刺激機能に重大な影響を及ぼすものではないと考える。

電気刺激実験では, 反対領域一の刺激で誘発される壁面 側と緩斜面側の反応 $\left(\mathrm{R}_{\mathrm{ws}}, \mathrm{R}_{\mathrm{sw}}\right)$ に有意な差が見られた。両 領域間で対称に情報が伝達されていれば，このような差は 生じない。よって, 非対称な三次元微細構造が, 両神経細 胞群間の情報伝達方向に何らかの指向性を与えたものと考 える。また, $\mathrm{R}_{\mathrm{sw}}$ のピーク值が $\mathrm{R}_{\mathrm{ws}}$ のそれよりも小さかった ことは，緩斜面側から壁面側への方向に指向性が生じてい たことを示唆している。このような指向性が生じた機序と して, 緩斜面側から壁面側への軸索伸長に比べて壁面側か ら緩斜面側への伸長が抑制され, 後者の方向への情報伝達 を担うシナプス結合の数が前者のそれと比べて少なくなっ たことが考えられる。しかし，本研究では，これらの形態 的な証左を得るには至らなかった。今後, 免疫抗体染色な どを用いて, 微細構造周辺の軸索伸長や, 両領域のシナプ ス数などを測定・比較する必要がある。なお, 樹状突起も 軸索と同様に, 壁面側から緩斜面側への伸長が抑制された と考えられるが, 最大伸長距離は軸索と比較して十分の一 程度と短く ${ }^{(17)}$, 情報伝達方向に与える影響は軽微であるこ とが推測される。

本研究では, 反対側刺激で誘発された反応について, 軸 索を介して逆行的 (antidromic) に誘発された反応と, シナ プス入力で誘発される反応とを区別せずに扱った。しかし， 培養した試料では, 緩斜面側から壁面側へ, またはその逆 方向に, 三次元構造を乗り越えて軸索が伸長されている様 子が確認された。そのため, 反対側の領域が刺激されてい た場合でも，シナプス伝達を介さず，軸索への刺激で直接 反応を誘発された神経細胞が存在したことが予想される。 その場合, 本研究で用いた刺激・解析手法では, シナプス を介した情報伝達量を選択的に抽出できない。より正確に 情報伝達方向の指向性を評価するには, 薬理的にシナプス 伝達を阻害した状態での刺激結果と, 通常の刺激結果との 差分をとることで, 逆行的に誘発された反応の影響を相殺 するなどの操作が必要になると考える。

\section{5. おわりに}

本研究では, 非対称な三次元微細構造を有する培養基板 を設計・試作し, 同構造で隔てられた神経細胞群間の情報 伝達方向に指向性を持たせることを試みた。同基板は，壁 面と緩斜面から成る三次元構造とその両側に包埋された刺 激電極とで構成される。切削加工で微細溝を形成した金型 に，ポリスチレン板を押しつけて加熱することで，所望の 
形状と電極を有する基板を製作できた。製作した基板上で 神経細胞を培養し, 情報伝達方向の指向性の有無を検証す るために, 三次元構造の両側の電極からそれぞれ電気刺激 を与えた。誘発された反応をカルシウムイメージングで計 測したところ，緩斜面側への刺激で誘発される壁面側の神 経細胞群の反応と, 壁面側への刺激で誘発される緩斜面側 の反応に有意な差があることがわかった。前者よりも後者 が小さかったことから, 緩斜面側から壁面側への方向に情 報伝達の指向性が生じたと考えられる。以上より，非対称 な三次元微細構造を用いて, 神経細胞群間の情報伝達方向 に指向性を与えられることが示唆された。

本研究は, 財団法人東電記念科学技術研究所の助成を受 けた。

(平成 19 年 10 月 26 日受付, 平成 20 年 3 月 14 日再受付)

\section{文献}

(1) V. B. Mountcastle : "The columnar organization of the neocortex", Brain, Vol.120, pp.701-722 (1997)

(2) S. Shipp : "Structure and Functions of the Cerebral Cortex", Curr. Boil., Vol.17, pp.R443-449 (2007)

( 3 ) M. Merz and P. Fromherz : "Polyester Microstructures for Topographical Control of Outgrowth and Synapse Formation of Snail Neurons", Adv. Mater., Vol.14, pp.141-144 (2002)

(4) A. A. Prinz and P. Fromherz : "Electrical Synapses by guided growth of cultured neurons from the snail Lymnaea stagnalis", Biol. Cybern., Vol.82, pp.1-5 (2000)

( 5 ) H. Moriguchi, K. Takahashi, Y. Sugio, Y. Wakamoto, I. Inoue, Y. Jimbo, and K. Yasuda : "On-chip Neural Cell Cultivation Using AgaroseMicrochamber Array Constructed by a Photothermal Etching Method", Electrical Engineering in Japan, Vol.146, pp.37-42 (2004)

(6) I. Suzuki, Y. Sugio, Y. Jimbo, and K. Yasuda : "Individual-Cell-Based Electrophysiological Measurement of a Topographically Controlled Neuronal Network Pattern Using Agarose Architecture with a Multi-Electrode Array”, Jpn. J. Appl. Phys., Vol.43, pp.403-406 (2004)

( 7 ) O. Feinerman, M. Segal, and E. Moses : "Signal Propagation along Unidimensional Networks”, J. Neurophysiol., Vol.94, pp.3406-3416 (2005)

( 8 ) D. Kleinfeld, K. H. Kahler, and P. E. Hockberger : "Controlled Outgrowth of Dissociated Neurons on Patterned Substrates", J. Neurosci., Vol.8, pp.4098-4120 (1988)

(9) N. W. Dowell-Mesfin, M.-A. Abdul-Karim, A. M. P. Turner, S. Schanz, H. G. Craighead, B. Roysam, J. N. Turner, and W. Shain : "Topographically modified surfaces affect orientation and growth of hippocampal neurons", J. Neural Eng., Vol.1, pp.78-90 (2004)

(10) N. Li and A. Folch: "Integration of topographical and bio chemical cues by axons during growth on microfabricated 3-D substrates", Exp. Cell Res., Vol.311, pp.307-316 (2005)

(11) H. Paranov, H. K. Rasmussen, N. B. Larsen, and N. Gadegaard : "On the injection molding of nanostructured polymer surfaces”, Polym. Eng. Sci., Vol.46, pp.160-171 (2006)

(12) O. Garaschuk, J. Linn, J. Eilers, and A. Konnerth : "Large-scale oscillatory calcium waves in the immature cortex", Nat. Neurosci., Vol.3, pp.452-459 (2000)

(13) E. Yaksi and R. W. Friedrich : "Reconstruction of firing rate changes across neuronal populations by temporally deconvolved $\mathrm{Ca}^{2+}$ imaging", Nat. Methods, Vol.3, pp.377-383 (2006)

(14) Y. Jimbo, T. Tateno, and H. P. C. Robinson : "Simultaneous induction of pathway-specific potentiation and depression in networks of cortical neurons", Biophys. J., Vol.76, pp.670-678 (1999)

(15) Y. Jimbo, H. P. C. Robinson, and A. Kawana : "Simultaneous measurement of intracellular calcium and electrical activity from patterned neural networks in culture", IEEE Trans. Biomed. Eng., Vol.40, pp.804-810 (1993)

(16) Y. Ikegaya, M. L. Bon-Jego, and R. Yuste : "Large-scale imaging of cortical network activity with calcium indicators", Neurosci. Res., Vol.52, pp.132-138 (2005)

(17) A. Lorenzo, H. Díaz, H. Carrer, and A. Cáceres : "Amygdala Neurons In Vitro: Neurite Growth and Effects of Estradiol”, J. Neurosci. Res., Vol.33, pp.418-435 (1992)

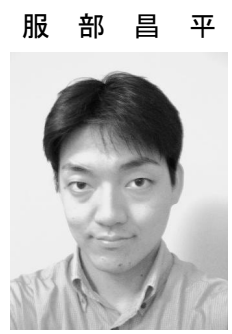

（非会員） 1983 年 2 月 12 日生。 2005 年 3 月東 京大学工学部 (産業機械工学科) を卒業。現在 同大大学院工学系研究科 (産業機械工学専攻) 修士課程に在学中。神経細胞培養デバイスの研 究に従事。

硯川潤

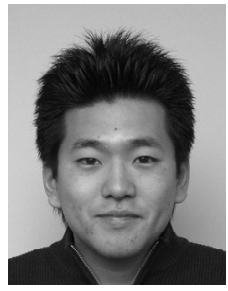

(学生員) 1981 年 8 月 15 日生。2006 年東京大 学大学院工学系研究科 (産業機械工学専攻) 修 士課程を修了。現在, 東京大学大学院情報理工 学系研究科（知能機械情報学専攻）博士課程に 在学中。神経工学, 生体電子工学の研究に従事。 電気学会, IEEE 等会員。

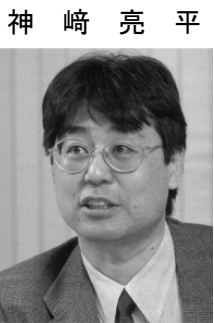

（非会員） 1957 年 4 月 4 日生。1986 年筑波大 学大学院生物科学研究科博士課程修了。1987 年アリゾナ大学神経生物学研究所博士研究員。 1991 年筑波大学生物科学系助手, 講師, 助教授。 2003 年同教授。2004 年東京大学大学院情報理 工学系研究科知能機械情報学専攻教授。2006 年東京大学先端科学技術研究センター生命知 能システム分野教授。神経行動学, 生体-機械融 合システムに関する研究に従事。国際神経行動学会, 日本動物学会, 日本比較生理生化学会等会員。理学博士。

神 保 泰 彦

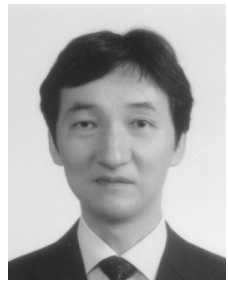

濱口哲也

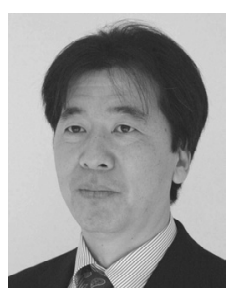

(正員） 1988 年東京大学大学院（電子工学） 修了, 工学博士。同年, NTT 基礎研究所研究員。 1992１993 年，フランス CNRS 客員研究員。 2003 年, 東京大学大学院工学系研究科精密機械 工学専攻助教授, 2006 年より同新領域創成科学 研究科人間環境学専攻教授。主として, 神経工 学の研究に従事。電子情報通信学会, 神経科学 学会, 日本生体医工学会, IEEE 等の会員。

（非会員） 1960 年 11 月 30 日生。1986 年東京 大学大学院工学系研究科（産業機械工学専攻) 修士課程を修了。同年, （株）日立製作所に入 社。2002 年東京大学大学院工学系研究科 (産業 機械工学専攻) 助教授として赴任。2007 年より 同社会連携講座特任教授。ナノ・マイクロ加工, トライボロジーに関する研究, 及び創造設計教 育に従事。博士（工学）。 
高橋宏 知 (正員) 1975 年 7 月 19 日生。 2003 年東京大

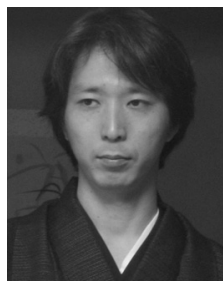

学大学院工学系研究科（産業機械工学専攻）博

士課程を修了。同年, 同大大学院工学系研究科

（産業機械工学専攻）助手, 2004 年, 同情報理 工学系研究科（知能機械情報学専攻）講師を経

て, 2006 年より東京大学先端科学技術研究セン

ター講師。福祉工学, 感覚代行デバイスの開発,

聴覚生理学など，医学・工学の境界領域の研究

に従事。生体医工学会, 電気学会等会員。博士（工学）。
中 尾 政 之 (正員) 1958 年 9 月 24 日生。1983 年東京大

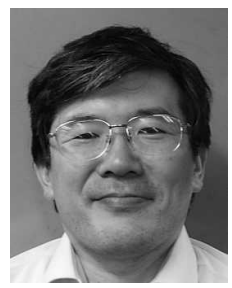
学大学院工学系研究科 (機械工学専攻) 修士課 程を修了。同年日立金属（株）に入社。1989 年から HMT Technology Corp.に出向。1992 年東 京大学大学院工学系研究科（産業機械工学専 攻) 助教授として赴任。2001 年東京大学工学部 附属総合試験機構教授, 2006 年より東京大学大 学院工学系研究科 (産業機械工学専攻) 教授。 創造設計のためのナレッジマネージメント, ナノ・マイクロ加工, および超精密加工とその産業界への応用に従事。博士（工学）。 